\title{
A new genus and species and a revised phylogeny of Stereomerini (Coleoptera, Scarabaeidae,Aphodiinae), with notes on assumedly termitophilic aphodiines
}

\author{
Hege Vårdal ${ }^{1, \dagger}$, Mattias Forshage ${ }^{1,2, \ddagger}$ \\ I Department of Entomology, Swedish Museum of Natural History, Box 50007, SE-10405 Stockholm, Sweden \\ 2 Department of Systematic Biology, Evolutionary Biology Centre, Uppsala University, Norbyvägen 18D, SE- \\ 75236 Uppsala, Sweden \\ † urn:lsid:zoobank.org:author:C87892C8-EE6B-4520-8402-85FD0E297455 \\ †urn:lsid:zoobank.org:author:F26F07CF-D637-4897-8EE4-D7BC805A196B \\ Corresponding author: Hege Vardal (hege.vardal@nrm.se) \\ Academic editor: Brett Ratcliffe | Received 1 September 2009 | Accepted 5 November2009 | Published 28 January 2010 \\ urn:lsid:zoobank.org:pub:4E78321B-96D8-4C57-A3C5-79E38C713F4E \\ Citation: Vårdal H, Forshage M (2010) A new genus and species and a revised phylogeny of Stereomerini (Coleoptera, \\ Scarabaeidae, Aphodiinae), with notes on assumedly termitophilic aphodiines. In: Ratcliffe B, Krell F-T (Eds) Current \\ advances in Scarabaeoidea research. ZooKeys 34: 55-76. doi: 10.3897/zookeys.34.264
}

\begin{abstract}
A new genus and species of Stereomerini, Cheleion malayanum gen. n. and sp. n., are described based on a single specimen from the Malacca peninsula in Malaysia. It is the first stereomerine found on the mainland of the Asian continent. A key to genera of Stereomerini and a phylogenetic estimate of the stereomerines using 24 species representing 7 tribes of Aphodiinae based on 53 morphological characters. The phylogenetic analysis places the new species within the tribe Stereomerini as a sister to the monophyletic group including Adebrattia, Austaloxenella, Bruneixenus, Pseudostereomera and Stereomera. A survey is given of the various taxa of Aphodiinae that are termite and/or ant inquilines, or have been presumed to be so based on morphology, and their phylogeny is discussed.
\end{abstract}

\section{Keywords}

termite association, Aphodiinae tribes, synechthran morphology

Copyright H.Vårdal, M. Forshage . This is an open access article distributed under the terms of the Creative Commons Attribution License, which permits unrestricted use, distribution, and reproduction in any medium, provided the original author and source are credited. 


\section{Introduction}

The aphodiine tribe Stereomerini was erected by Howden and Storey in 1992 for four genera of minute, rare and supposedly termite-associated aphodiines Stereomera $\mathrm{Ar}$ row, Termitaxis Krikken, Australoxenella Howden and Storey, and Bruneixenus Howden and Storey (Howden and Storey 1992). In 1995 Bordat and Howden excluded Termitaxis from the tribe and described 3 new genera and species: Adebrattia depressa Bordat and Howden, Danielssonia minuta Bordat and Howden and Pseudostereomera mirabilis Bordat and Howden (Bordat and Howden 1995). Since then one new genus (Daintreeola Howden and Storey) and 11 new species of the genera Daintreeola, Bruneixenus and Australoxenella have been described (Storey and Howden 1996; Howden and Storey 2000). The number of genera of Stereomerini is presently 7 and the number of species 18, all from insular south east Asia and Australia.

Synapomorphies for the Stereomerini include a grooved head as well as a particular pattern of carinae and grooves on the pronotum with three pronotal carinae concentrated in median third and one transverse groove, plus convex body shape, wide epipleura and reduced eyes. Characters that may be either apomorphic or plesiomorphic are a more or less lanceolate posterior prosternal process, clypeus without dentation and flattened tibiae (Forshage 2002).

In the collections of the Swedish Museum of Natural History (NHRS) we found a remarkable specimen clearly belonging to Stereomerini but representing a new undescribed taxon, the first one from a locality on the Eurasian continent (the Malaysian Peninsula). As it has not been possible to accommodate the new taxon in one of the existing genera we felt impelled to describe a new genus as well. In order to test this, we performed a phylogenetic analysis of all the genera of Stereomerini. As the relationships between various aberrant tribes within the Aphodiinae, and between those tribes and the poorly delineated Eupariini, we included a wealth of other genera in the analysis.

\section{Methods}

Images of the new species were obtained with a digital Olympus DP70 camera mounted on an Olympus SZX12 stereo microscope using the imaging software AnalySIS 5.0 to montage section images with different focus. Micrographs were taken with a Zeiss Supra35VP scanning electron microscope on low vacuum. The low vacuum scanning electron microscopy does not require the specimen to be prepared in the traditional manner including critical point drying and gold-coating and is thus particularly suitable for type material. Character coding of the new taxon and other taxa at hand were done from a combination of stacked digital images and direct observation in stereo microscope. Taxa not at hand were coded from scorings and images found in literature. These include Australoxenella humptydooensis Howden and Storey, Bruneixenus squamosus Howden and Storey, Cartwrigthia intertribalis Islas, Ascharhyparus peregrinus (Hinton), Termitodiellus es- 
akii Nomura and Stereomera pusilla Arrow and Termitaxis holmgreni Krikken coded from Howden and Storey (1992), Daintreeola grovei Howden and Storey coded from Howden and Storey (2000) and Termitoderus ultimus Krikken coded from Krikken (2008a).

Our images of the following taxa are deposited on Morphbank (http://www.morphbank.net); the new taxon (Cheleion malayanum n.sp.) (image numbers 480710480723) and of the types of the rare Danielssonia minuta (image numbers $497197-$ 497199), Pseudostereomera mirabilis (image numbers 497204-497207) and Adebrattia depressa (image numbers 497200-497203) (all Bordat and Howden 1995)

\section{Character selection}

Several of the characters have been used in previous phylogenetic analyses (Howden and Storey 1992; Bordat and Howden 1995, Forshage 2002). In an attempt to further define the tribe Stereomerini based on morphological characters, we have added several characters (see Table 2) on the head (characters 4, 5, 10,11), pronotum (characters $15,18,20,22,23,24)$, legs (characters 34, 35), wings (characters 37, 38, 39, 44, 45), abdomen (characters 46,53 ). We did not want to dissect the single type specimen of the new taxon so we have not been able to compare mouthparts and genitalia which are potential valuable sources of additional characters.

\section{Taxon selection}

For the phylogenetic analysis we included representatives from all genera of the tribe Stereomerini, as this was our primary group of interest. In addition we wanted to include representatives of the tribes believed to be closely related to the Stereomerini based on morphology as well as some taxa of unclear taxonomic status and phylogenetic position. In addition to the 8 Stereomerini species, we thus coded 5 species of Rhyparini (Aschnarhyparus peregrinus, Termitodiellus esakii, Rhyparus suturalis Schmidt, Cartwrightia intertribalis and Sybacodes simplicicollis Fairmaire), 1 species of Termitoderini (Termitoderus ultimus Krikken), 1 species of Termitotrogini (Termitotrox consobrinus Reichensperger), 2 species of Corythoderini (Corythoderus loripes Klug and Neochaetopisthes heimi Wasmann) as well as Termitaxis holmgreni (incertae sedis). As these aberrant taxa are of uncertain relationships with Eupariini - possibly differently to different parts of Eupariini - we wanted to include a fair representation of the diversity of that tribe. Thus we included a representative of an aberrant genus, morphologically similar to some of the truly or assumedly termitophilous tribes (Notocaulus sculpturatus Boheman), plus the largest genera of the tribe (Ataenius scabrelloides Petrovitz and Saprosites laeviceps Harold), as well as the type genus of the tribe (Euparia castanea LePeletier and Serville). As outgroup taxa we chose Aphodiini, since they are the major group of Aphodiinae that we expect to be safely outside the group of interest here; we included one more or less typical and one aberrant representative of Aphodiini (Aphodius elegans Allibert and Sybax impressicollis Boheman). 


\section{A note on the type specimen of Termitotrox}

The type specimen of the type species of the type genus of Termitotrogini, Termitotrox consobrinus Reichensperger 1915, was long considered lost (Paulian 1985), but was recently rediscovered by author MF in a cabinet at the Lund museum, where it was left forgotten many years ago by B-O Landin who was acting as a courier between the Gothenburg museum where it was originally deposited and professor Balthasar in Prague who had borrowed it. The specimen is now again available at the Natural History Museum in Gothenburg.

\section{Phylogenetic estimate}

Fifty three morphological characters (Table 2) were coded for 24 species from 7 tribes of Aphodiinae (Table 3). Fourteen of the species were coded from specimens, whereas 10 were coded from literature. Character 10 is ordered, while all other multistate characters are unordered. Uniform weights were applied. The phylogenetic analyses were performed in Paup* Portable version 4.0b10 for Unix (Swofford 2002). Character evolution was explored using MacClade 4.08 (Maddison and Maddison 2005). Heuristic searches produced three equally parsimonious trees with 195 steps. Ensemble consistency index is 0.345 and retention index is 0.589 .

\section{Results}

An identification key for the genera of Stereomerini is given in Table 1.

\section{Table I. Identification key to the genera of Stereomerini}

1. Elytra modified laterally or posteriorly ……............................................

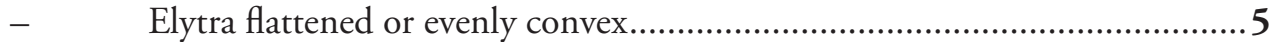

2. Margin of clypeus with pronounced inflexion, triangular at apex; pronotum with conspicuous depressions laterally; deep lateral longitudinal furrow on each elytron Danielssonia Bordat \& Howden

- $\quad$ Margin of clypeus weakly inflexed; pronotum not laterally depressed; elytra conspicuously declivous posteriorly, deep elytral furrow missing 3

3. Elytra with strong transversal ridges Stereomera Arrow Elytra without strong transversal ridges.

4. Elytral costae strongly twisted Pseudostereomera Bordat \& Howden

- Elytral costae subparalell, posterior elytral corners protruding

... Bruneixenus Howden \& Storey

5. Each elytron with pronounced and widely separated longitudinal costae; transverse striation missing or inconspicuous; elytral epipleura wide ...........6

- $\quad$ Each elytron lacking or with inconspicuous longitudinal costae; strong transverse striation on each elytron; elytral epipleura narrow 
6. Posterior prosternal process lanceolate; body covered by appressed circular scales giving surface a granular appearance ...........Australoxenella Howden \& Storey

- $\quad$ Posterior prosternal process hastate; body covered with large punctures/tubercles giving surface a rough appearance............................. Cheleion gen. n.

7. Body flattened; longitudinal elytral striae very weak, transverse striations profound; apical segment of maxillary palp securiform

Adebrattia Bordat \& Howden

- $\quad$ Body convex; longitudinal elytral striae pronounced with tranverse striations only on the lateral elytron; apical segment of maxillary palp cylindrical ........

Daintreeola Howden \& Storey

Table 2. List of characters used in data matrix for phylogenetic analysis

\begin{tabular}{l|l}
\hline General \\
\hline 1 & Entire dorsum with longitudinal costae: absent (0) or present (1) \\
\hline 2 & Body shape cylindrical (0), flattened (1) or strongly convex (2) (unordered) \\
\hline Head \\
\hline 3 & Head forward-pointing (0) or strongly retractable (1) \\
\hline 4 & Antenna shorter than (0) or longer than (1) length of head \\
\hline 5 & Maxillary palpi oval (0) or securiform (1) \\
\hline 6 & Eyes with distinct dorsal portion (0), reduced (lacking dorsal portion) (1), or absent (2) (unordered) \\
\hline 7 & Head posteriorly margined (1) or not (0) \\
\hline 8 & Head wide (1) or not wide (0) \\
\hline 9 & Anterior edge of clypeus inflexed (0), straight or slightly rounded (1) or pointed (2) (unordered) \\
\hline 10 & Reflexed apical portion of clypeus absent (0), perpendicular (1), fully inflexed (2) (ordered 0-1-2) \\
\hline 11 & Head grooves absent (0), present, parallel (1) or present, radial (2) (unordered) \\
\hline Pronotum \\
\hline 12 & Prosternal process inconspicuous (0) flattened (1) or raised (2) (unordered) \\
\hline 13 & Prosternal process inconspicuous (0) lanceolate (1) or hastate (2) (unordered) \\
\hline 14 & Scutellum minute (0) or absent (1) \\
\hline 15 & Pronotal anterior lateral angles evenly convex (0) or conspicuously depressed (1) \\
\hline 16 & Pronotal sides concave (0), parallel (1) or convex (2) \\
\hline 17 & Pronotal transverse furrow absent (0), basal (1), medial (2) or frontal (3) (unordered) \\
\hline 18 & Pronotal transverse furrow absent (0), shallow (1), or deep (2) (unordered) \\
\hline 19 & Pronotal posterior lateral angles protruding (1) or not protruding (0) \\
\hline 20 & Pronotal basal medial lobe protruding (1) or basal border evenly convex (0) \\
\hline 21 & Pronotum with (1) or without (0) broad lateral depressions \\
\hline 22 & Bulbous posterior submedian lobes on pronotum absent (0) or present (1) \\
\hline 23 & Pronotum anteriorly tapering (1) or of equal width (0) \\
\hline 24 & Anterior median pronotal knob absent (0), present (1) \\
\hline 25 & Denticulation of fore tibiae normal (three distinct teeth) (0) or reduced (1) \\
\hline 26 & Mid and hind tibial apical spurs pronounced (0) or reduced (1) \\
\hline
\end{tabular}




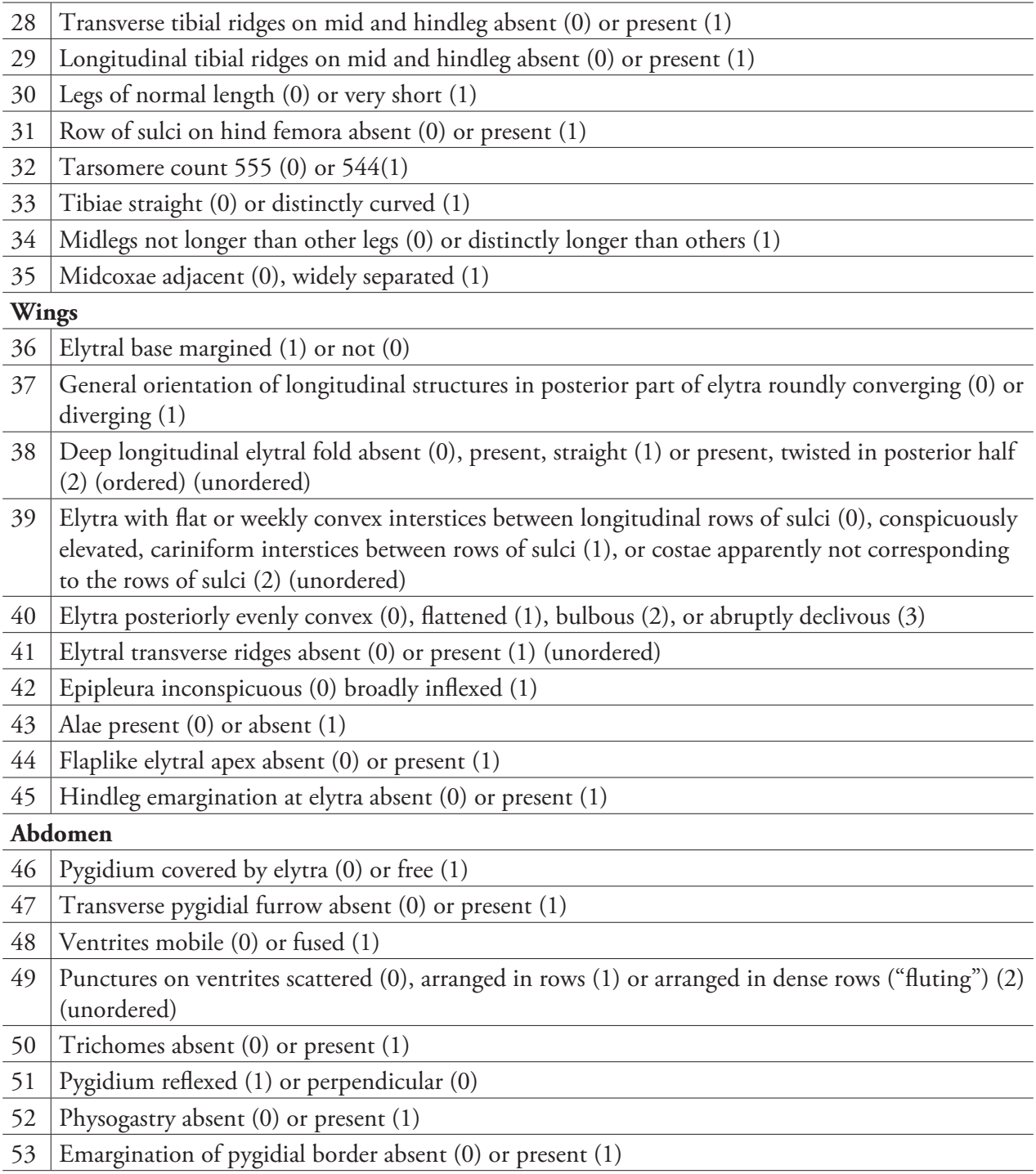

\section{Cheleion gen. $\mathbf{n}$.}

urn:Isid:zoobank.org:act:CC1002E4-849C-437A-BAEF-678474600B59

Type species. Cheleion malayanum sp. n., here designated.

Etymology. Genus name after the ancient Greek name for shell; gender is neuter.

Diagnostic characters. The body shape of the imago is strongly convex and the elytra are not conspicuously modified posteriorly. Large tubercles on the entire body surface give a rough appearance. Longitudinal grooves on the pronotum converge into a median transversal groove giving it an hourglass pattern. The posterior prosternal process is hastate. 
Table 3. Data matrix based on characters in Table 1

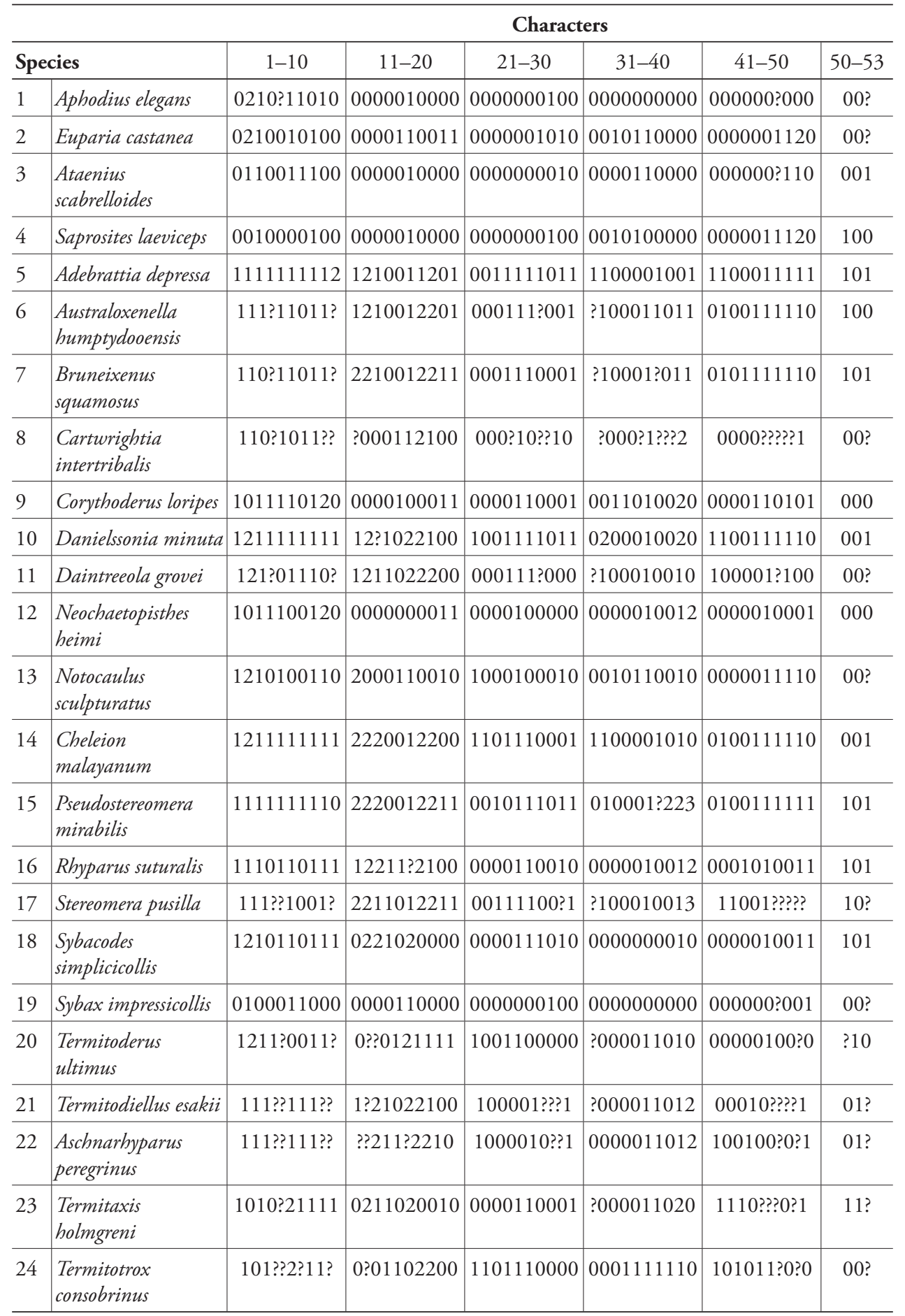


Immature stages unknown.

Description. Dorsal surface. Head very wide, subrectangular dorsally, clypeus apically pointed and reflexed under head, frons slightly bulbous with 5 divergent furrows; posterior transverse furrow running across the head from the posterolateral side of the one eye across to the posterolateral side of the other eye. Antennae long, length equivalent to width of head; amber-color, with long setae. Maxillary palpi length equivalent to length of head, amber-color, with securiform apical segment. Labial palpi with long setae on apices. Eyes have no distinct dorsal part and mouthparts are retracted.

Pronotum large and transverse, sides evenly curved, anterior edge bisinuate, posterior edge with a broad median protrusion. Disc of pronotum medially with 5 furrows, converging towards the middle in an hourglass pattern, midfurrow shallower than lateral furrows. Anteromedial disc with distinctly raised tubercle, posteromedial disc and posterolateral sides with slightly lower tubercles. Lateral of the furrows are large elliptical depressions, delineated by furrows.

Hindbody narrower than pronotum, elytra only slightly longer than pronotum plus head.

Elytra posteriorly tapering, apically rounded, evenly, not abruptly (declivous) posteriorly. Each elytron with 6 longitudinal ridges before the lateral edge, elytral interstices alternating in height, elevated but discontinuous, consisting of series of longitudinal setae-bearing tubercles. Even interstices lower, rugose. Epipleura broadly inflexed, posterior two thirds of lateral edge slightly recurved to allow free movement of hindlegs.

Pygidium exposed, strongly punctured proximally, less strongly apically. Small emargination on proximal pygidial border.

Ventral surface. Prosternal process strongly elevated and apex expanded, transversely split anterior to procoxae, hastate posterior to procoxae. Mesosternum narrow with alutaceous and punctured surface. Metasternum triangular widest in front and tapering posteriorly, groove along midline, surface nitid and punctured. Abdomen with 5 segments visible ventrally.

Ventrites apparently fused.

Legs short with broad femora and tibiae, tarsi 4-segmented and short. Fore tibiae moderately wide, with finely serrated outer edge and one strong apical lateral tooth, tarsus inserted well before apex. Mid and hind tibiae broad with finely serrated outer edge and concave apex; each with at least two inconspicuous tibial spurs.

\section{Cheleion malayanum sp. $\mathbf{n}$.}

urn:lsid:zoobank.org:act:D8732C0E-4747-4276-8F27-2354509159F3

Material. Holotype: Malaysia, Pahang, Bukit Frazer, 1200 m, 7-9/4 - 1992, Malaisetrap in jungle, Heikki Hippa leg. Swedish Museum of Natural History (NHRS).

Etymology. The first specimen of the species was collected in Malaysia.

Diagnostic characters. Structures such as the hastate posterior prosternal process, pattern on the pronotum with a strong anteromedial knob as well as bulbous areas 
medially and laterally on each side at the posterior end of the pronotum, the very long antennae and the strongly tuberculate and rugose surface of the body will easily separate this species from other known Stereomerini.

Description. Length $1.8 \mathrm{~mm}$, width at broadest point $0.9 \mathrm{~mm}$. Chestnut brown, whole body rather densely covered with strong puncture; strongly convex. Morphology as in generic description and as in Figures 1-6.

\section{Phylogenetic estimate}

The three resulting most parsimonious trees (Figure 7A-C) differ only in the internal relationships within the Steremerini genera Australoxenella, Bruneixenus, Pseudostereomera, Stereomera and Adebrattia (as shown in the consensus tree, Figure 7D). The rest of the Stereomerini species, namely the new taxon, Danielssonia and Daintreeola appear in the same positions in all three trees (Figure 7A-C). None of the three configurations corresponds very well with Bordat and Howden's (1995) cladogram (we do not compare with Storey and Howden as they only included three representatives of
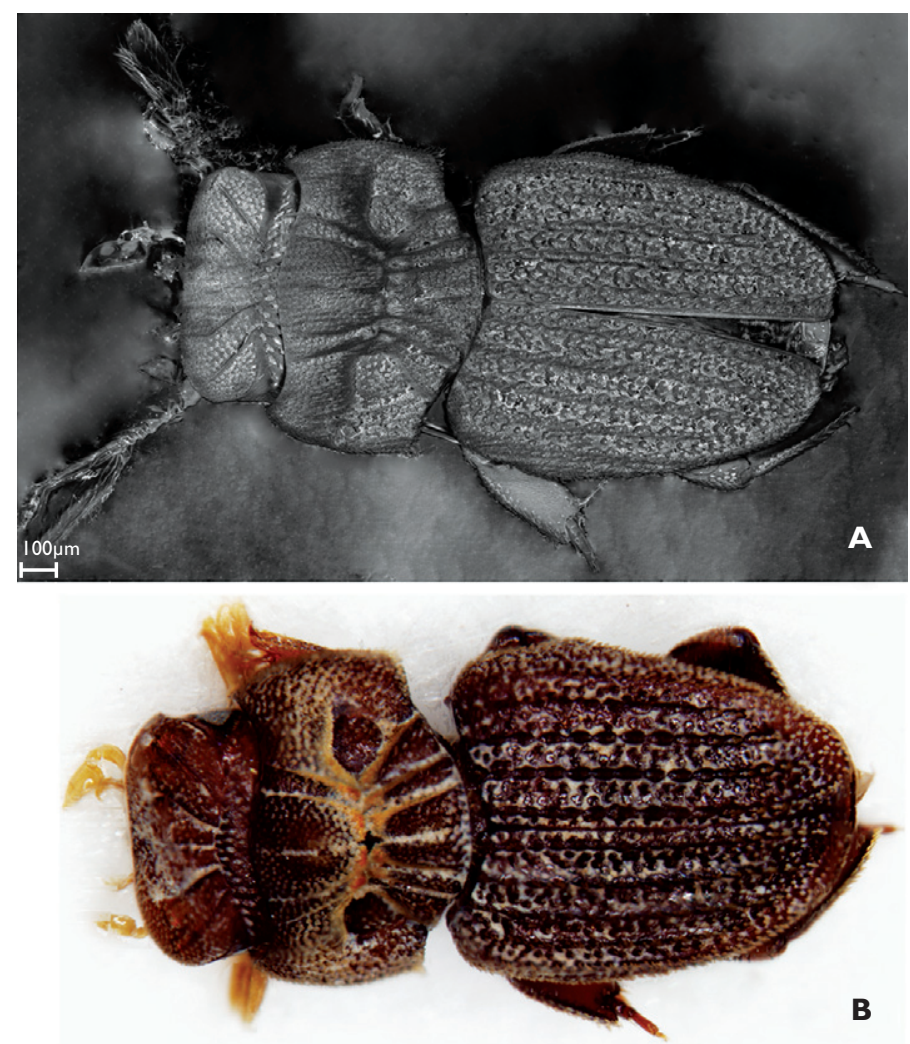

Figure I. Dorsal view of Cheleion malayanum sp. n. A scanning electron micrograph B stereo microscope image. 

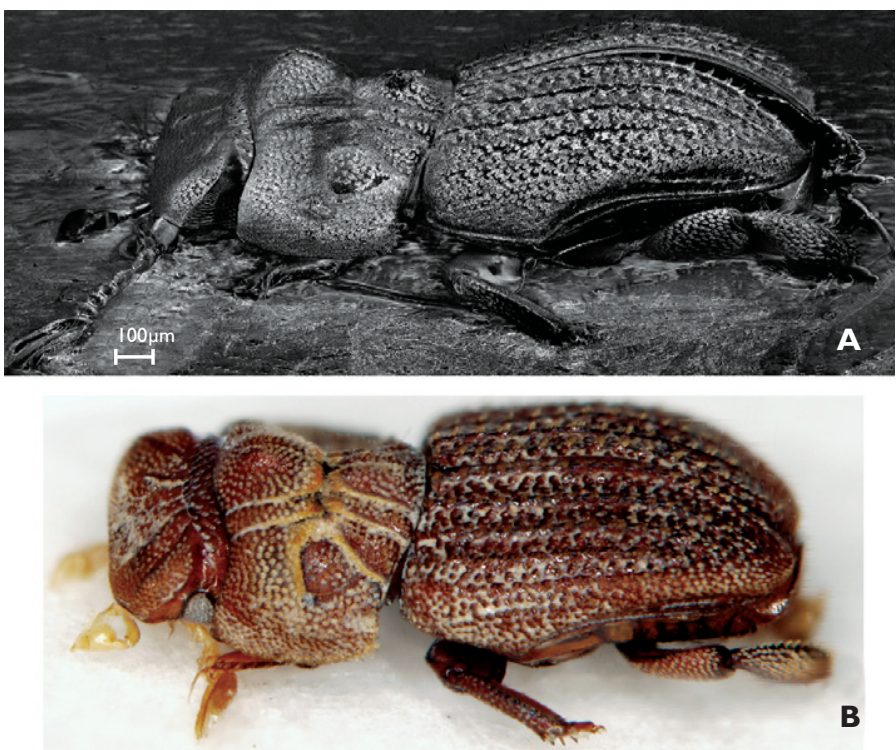

Figure 2. Lateral view of Cheleion malayanum sp. n. A scanning electron micrograph B stereo microscope image.

Stereomerini in their 1992 analysis) in which the sister species Adebrattia-Bruneixenus forms a sister group to Danielssonia-Australoxenella-(Stereomera-Pseudostereomera). One reason for this may be that neither the new taxon nor Daintreeola were included in the Bordat and Howden (1995) analysis. Our results rather points to a close relationship between Adebrattia and Pseudostereomera and between Australoxenella and Bruneixenus. Stereomera was placed as a sister group to the Adebrattia-Psendostereomera in 2 of the 3 trees and as sister group to Australoxenella-Bruneixenus in the third tree.

Concerning the relationships outside Stereomerini, our results point to a close relationship between Stereomerini and the genus Termitaxis, that was formerly included in Stereomerini but is now considered incertae sedis (Bordat and Howden 1995), and the Termitotrogini (Termitotrox). Corythoderini appears monophyletic, as does a core of Rhyparini (if excluding Sybacodes, the position of which has been ambiguous, and Cartwrightia, previously classified in Eupariini and recently transferred to Rhyparini). All representatives of the aberrant tribes form a monophyletic group together, while the more typical Eupariini genera form a grade basal to this group.

\section{Discussion}

\section{History of classification of inquiline Aphodiinae}

There are several taxa in Aphodiinae which have inquiline or inquiline-like morphologies (listed in Table 4). They are usually small, have integumental bulbs and ridges, particularly longitudinal dorsal ridges; sometimes contracted body shapes; short, broad 

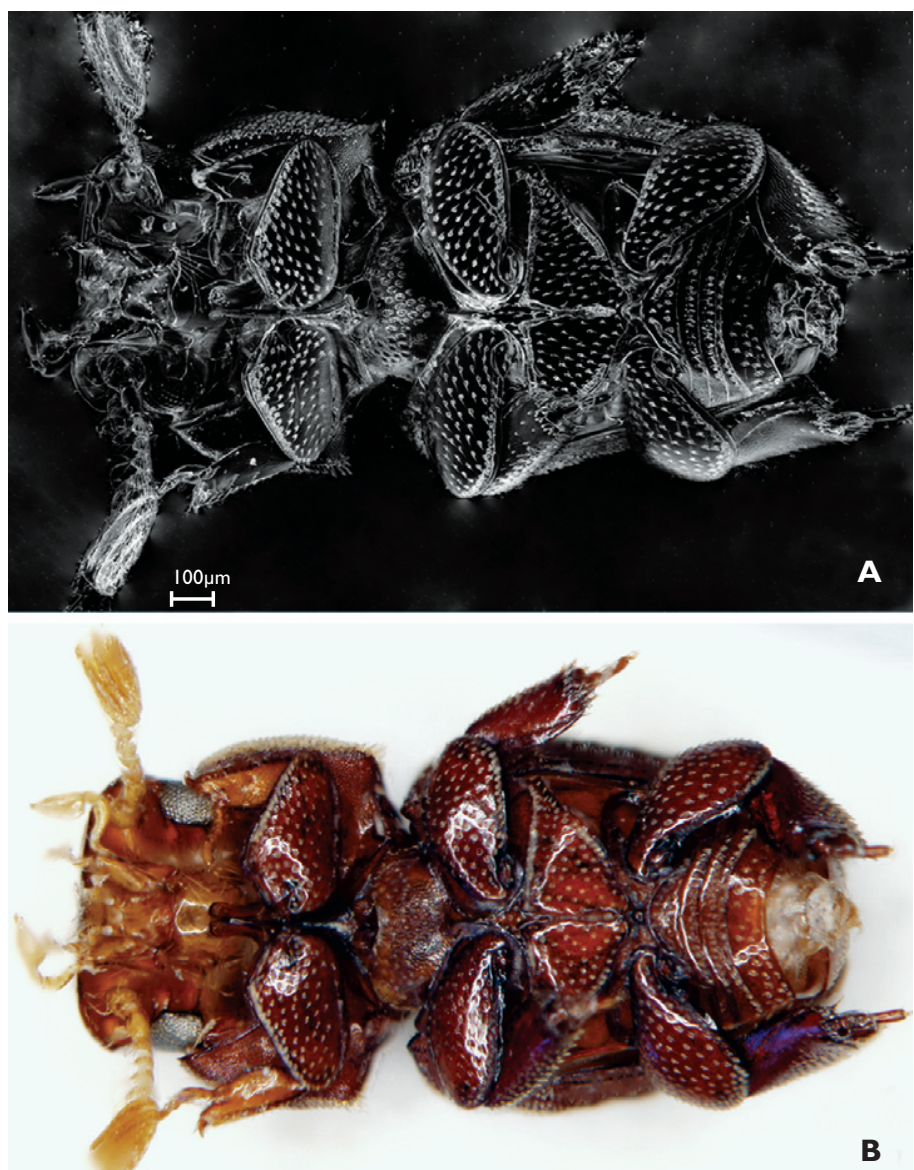

Figure 3. Ventral view of Cheleion malayanum sp. n. A scanning electron micrograph B stereo microscope image.

extremities, sometimes less so; and occasionally hair tufts or inflated abdomen. Their classification has included some moments of confusion.

In the first tribal division of Aphodiinae (Schmidt 1910), all the termitophilic or termitophile-like species were classified as Rhyparini and Corythoderini (only later were Termitotrox considered to be part of or closely related to Aphodiinae).

Termitoderini was added explicitly as a probable sister group to Corythoderini (Tangelder and Krikken 1982), and Stereomerini in a similar way as the sister group to Rhyparini (Howden and Storey 1992). The boundaries between all these tribes have been somewhat confused due to the uncertain status of some genera, and to the citing of all recent or problematic taxa as Termitoderini in Dellacasa's catalogue (Dellacasa 1987-88).

Termitoderini was erected as monotypic, but Dellacasa listed six genera there (including several from Rhyparini), which may have been a mere mistake, or a conscious reclassification with no arguments presented in the series of corrigenda to the cata- 


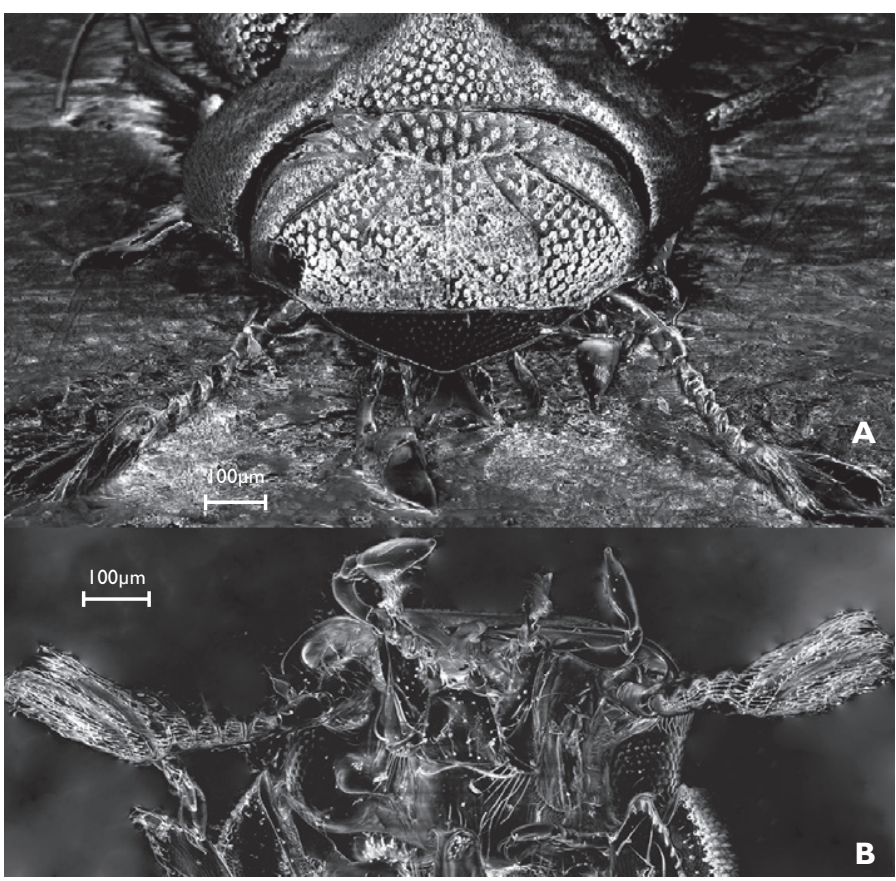

Figure 4. Head of Cheleion malayanum sp. n. A frontal view, scanning electron micrograph B ventral view, scanning electron micrograph.

logue. The genera that actually belonged to Ceratocanthidae were deleted ("dropped") but no further information given on the others (Dellacasa 1991).

If disconsidering Dellacasa's classification, it becomes rather straightforward: Termitaxis was described in Rhyparini (Krikken 1970) but removed to become incertae sedis (Howden and Bordat 1995), Cartwrightia was classified as Eupariini, but transferred to Rhyparini (Galante et al. 2003; Stebnicka 2009), Sybacodes were always considered Rhyparini but it has been questioned (Howden and Bordat 1995), Notocaulus were classified as Rhyparini, but transferred to Eupariini (Krikken and Huijbregts 1987; Howden and Storey 1992).

A number of more or less aberrant genera have been added to the Rhyparini in recent years (Howden 1995, 2003; Howden and Storey 2000; Makhan 2006; Pittino 2006), with Skelley (2007) making an effort to straighten up the classification and listing several papers describing new species or otherwise forwarding knowledge which are not listed here. Krikken $(2008 \mathrm{a}, \mathrm{b})$ recently reconsidered and described new species in Termitoderini and Termitotrogini.

In addition to these, a number of ant inquilines have always been present in the Eupariini, including the type genus Euparia, and two species which are termite inquilines. At one point, Stebnicka erected the tribe Lomanoxiini for the most aberrant Neotropical ant inquilines (Stebnicka 1999), but that was synonymized into Eupariini (Skelley and Howden 2003). All these Neotropical forms were recently reviewed and pictured in Stebnicka (2009). 


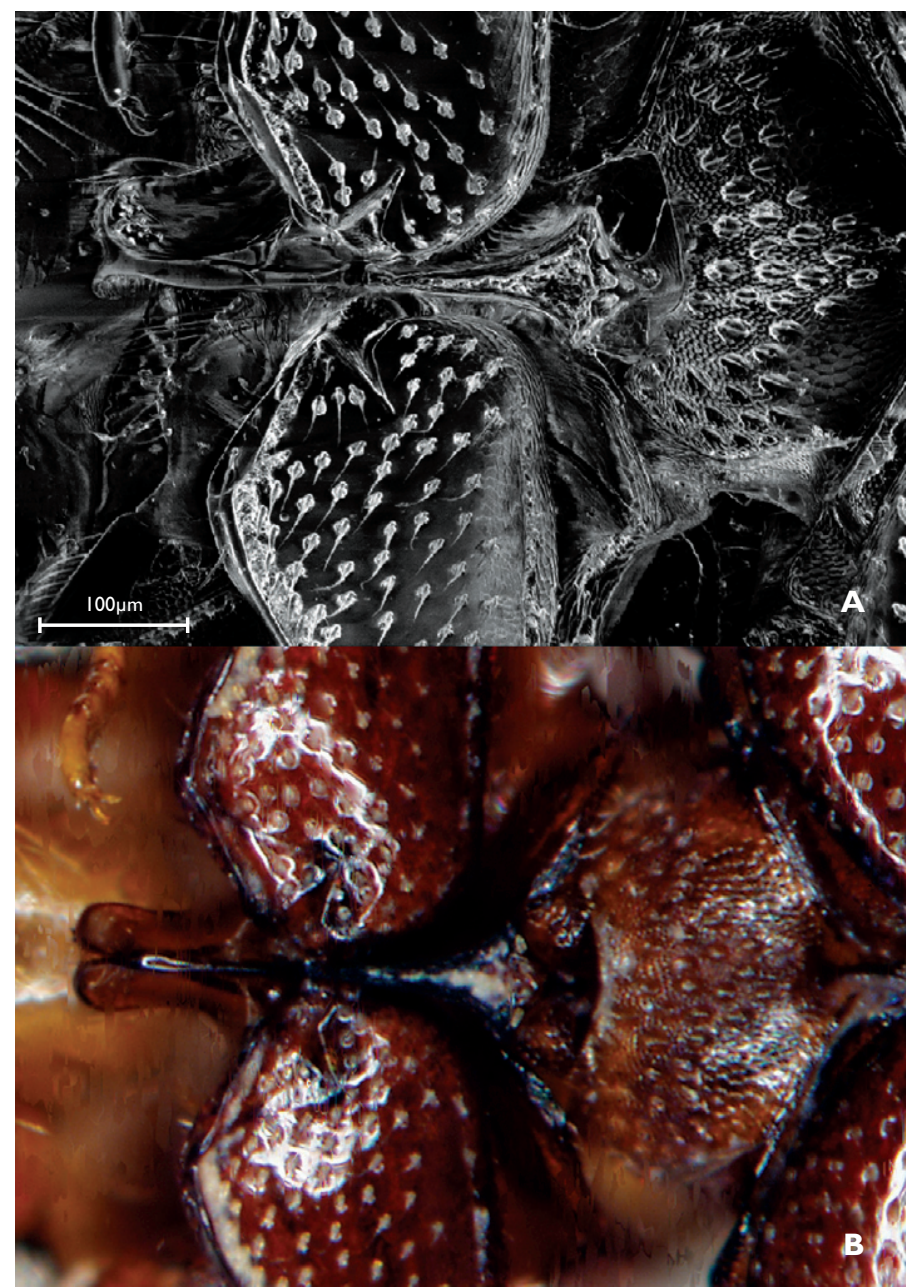

Figure 5. Posterior prosternal process of Cheleion malayanum sp. n. A scanning electron micrograph $\mathbf{B}$ stereo microscope image.

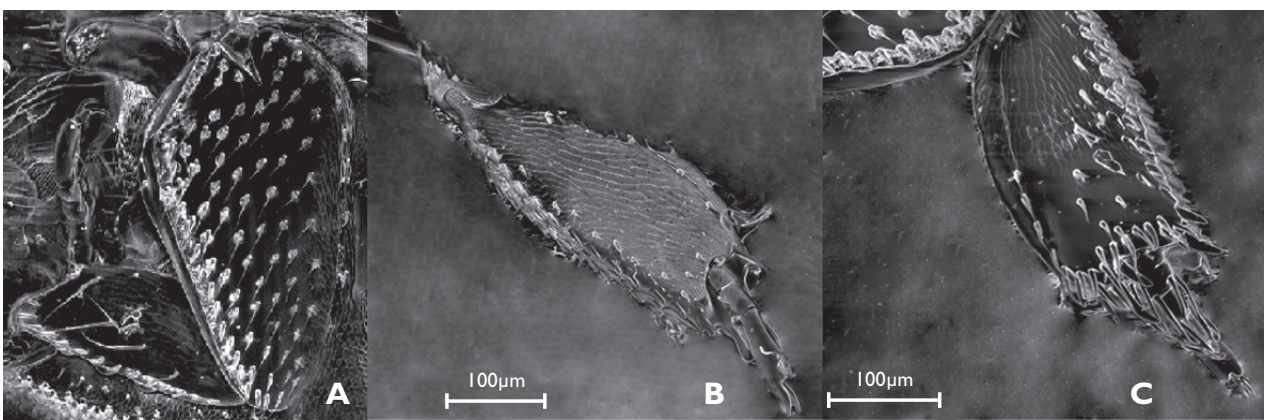

Figure 6. Legs of Cheleion malayanum sp. n. A scanning electron micrograph of foreleg $\mathbf{B}$ scanning electron micrograph of midleg showing unconspicous tibial spurs $\mathbf{C}$ scanning electron micrograph of hindleg. 


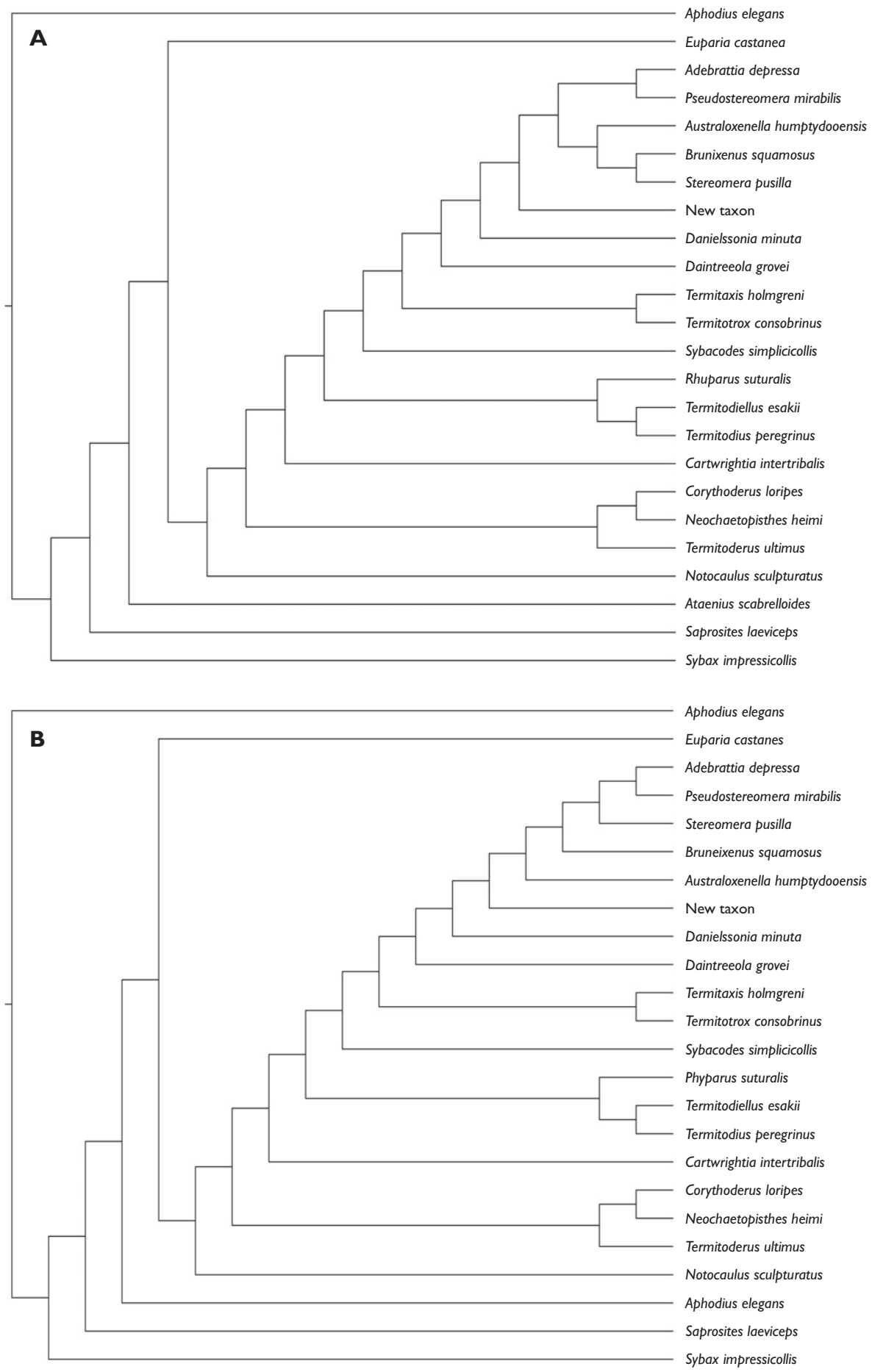

Figure 7. Resulting trees from phylogenetic analysis of morphological data of representatives of A-C The 3 most parsimonious trees $\mathbf{D}$ the strict consensus tree. 


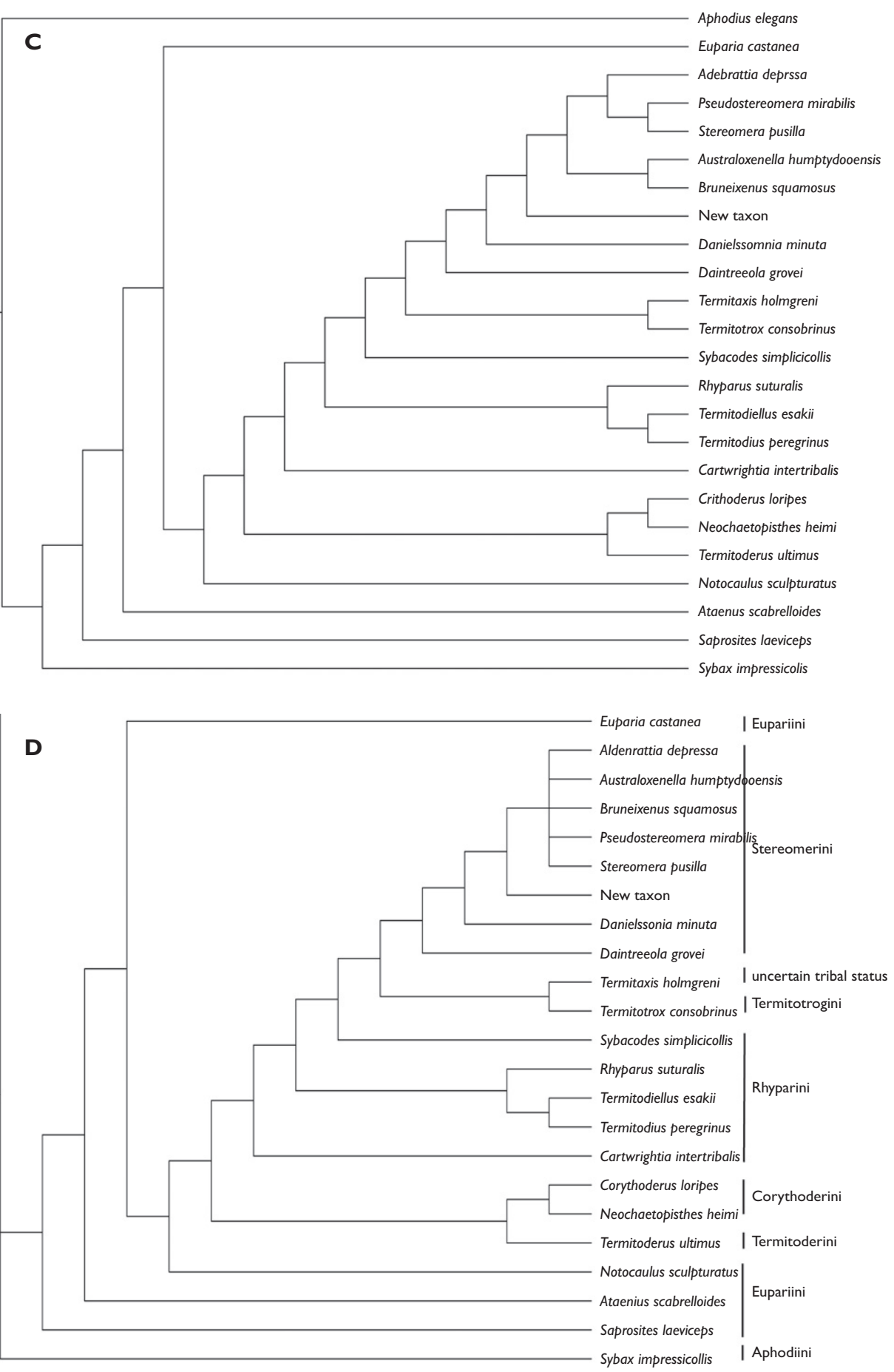

Stereomerini, Rhyparini, Corythoderini, Termitoderini, Termitotrogini, Aphodiini and Euparini. 


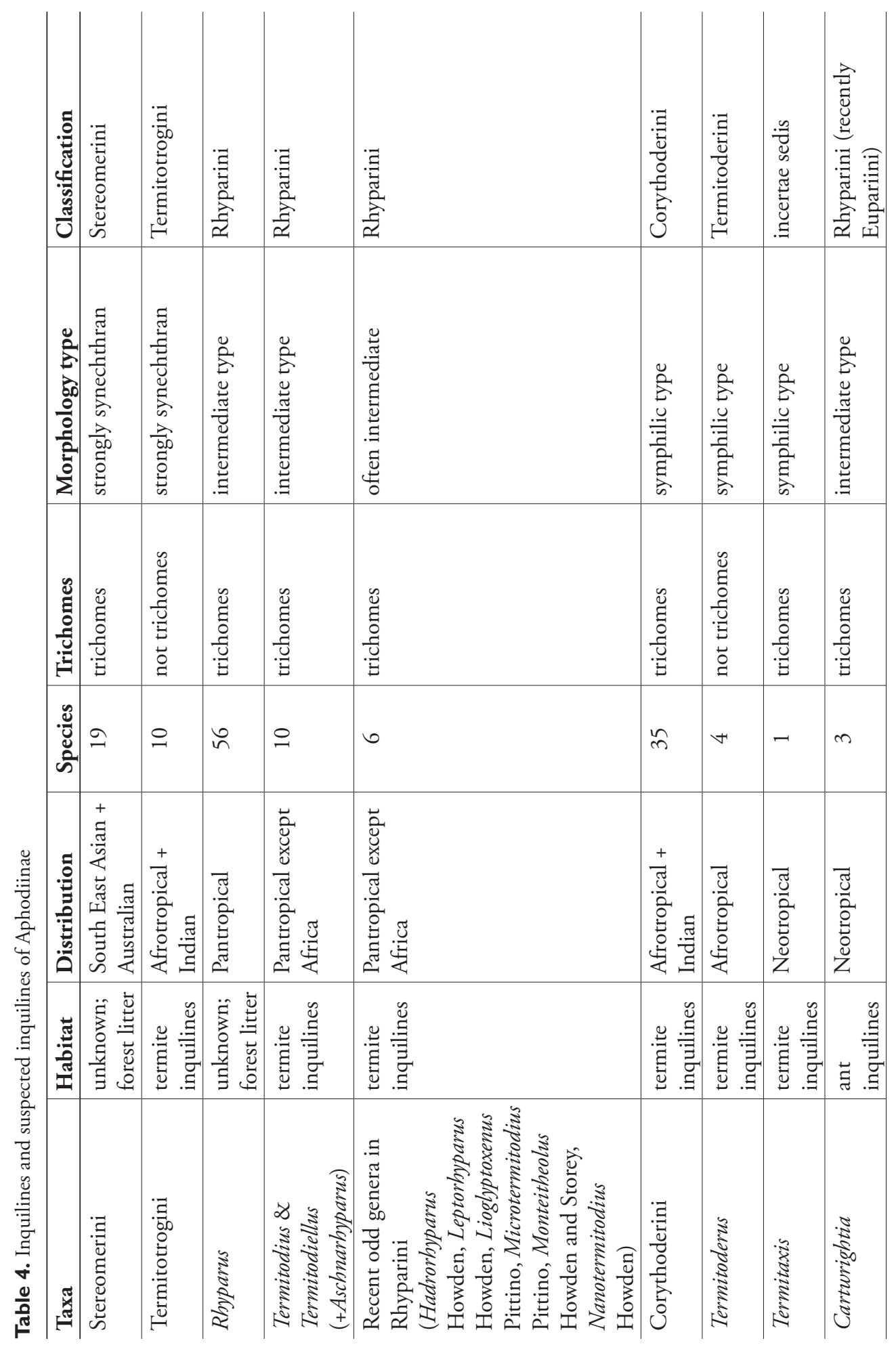




\begin{tabular}{|c|c|c|c|c|c|c|}
\hline & & & 荡 & 践 & 荡 & 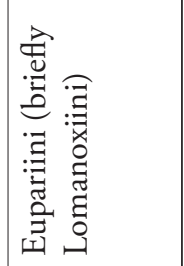 \\
\hline : & 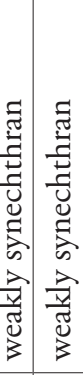 & 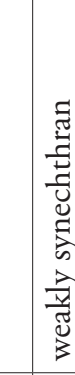 & 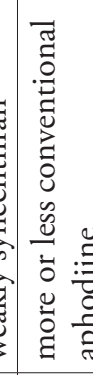 & 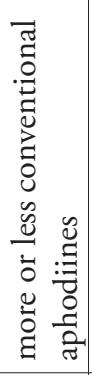 & 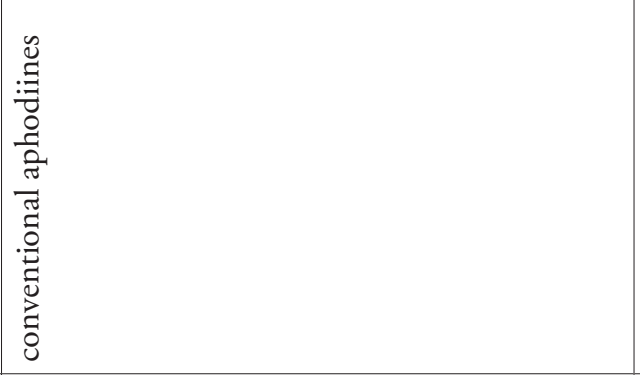 & 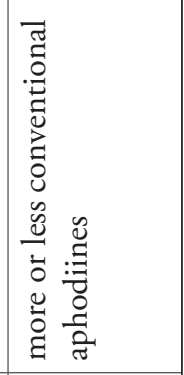 \\
\hline : & 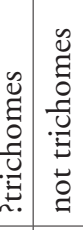 & 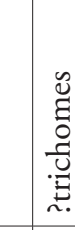 & 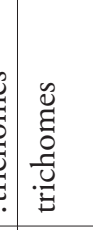 & 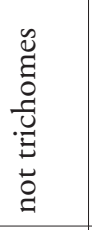 & 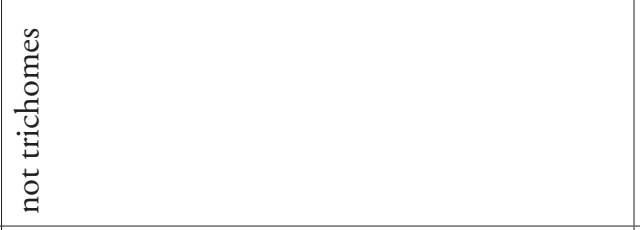 & 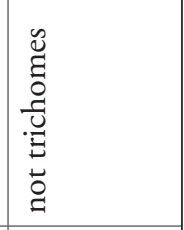 \\
\hline के & $m$ & $m$ & $=$ & $\sim$ & $\stackrel{0}{x}$ & ส \\
\hline أ. & & & 党 & 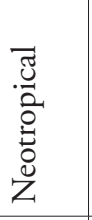 & 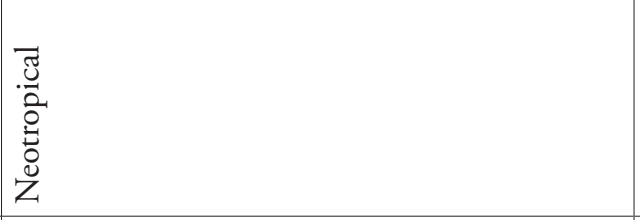 & 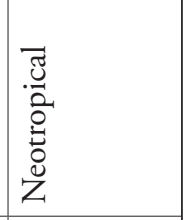 \\
\hline |. & & & 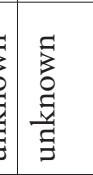 & 量 & 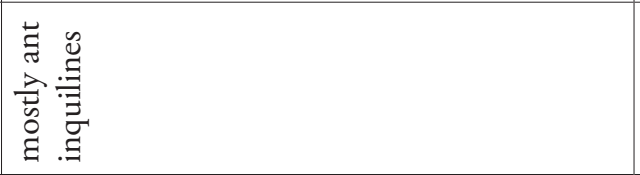 & 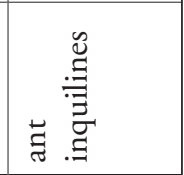 \\
\hline 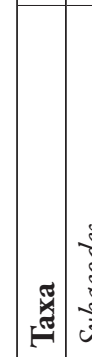 & 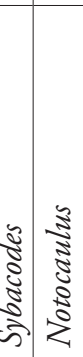 & & 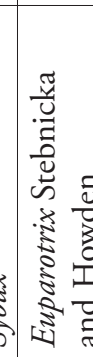 & 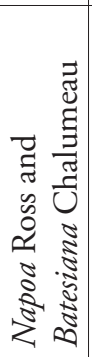 & 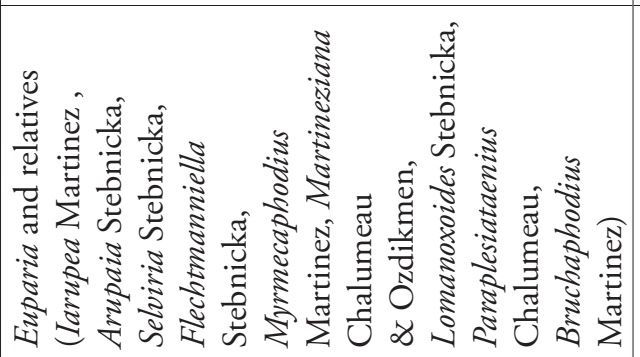 & 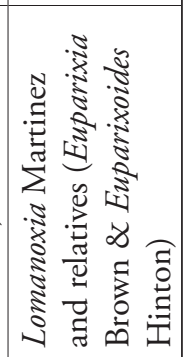 \\
\hline
\end{tabular}


The classification, and above all the relationships between the inquiline tribes, remains unsure because of the more or less far-reaching morphological specializations, including both obvious strongly derived specializations in habitus and integument, as well as reductions in characters traditionally used for distinguishing aphodiine tribes. Many of these specializations often overlap between the inquiline tribes, thus obscuring relationships between each other and between them and the large aphodiine tribe Eupariini, which is speciose in the tropics and characterized mainly by plesiomorphies visavis most other tribes of Aphodiinae.

Often, the appearance of tibial ridges and position of tibial apical spurs are used as diagnostic characters between Eupariini and Aphodiini. These characters are often useless in inquiline-type aphodiines with highly modified, short tibiae and reduced spurs. The abdominal characters traditionally used (fusing of sternites, pygidial furrow, etc.) often unite several but not all inquiline-type taxa with most Eupariini. Perhaps the dissection-requiring mouthparts and aedeagus, which both have provided characters considered important for aphodiine classification (Dellacasa et al. 2001 and elsewhere), but were not studied here, may provide useful information in this respect.

\section{Status of knowledge of biology of alleged inquilines}

Strangely enough, it is only some of these inquiline-looking taxa that are actually found in association with social insects. Actually associated with termites are Termitotrogini, Corythoderini, Termitoderini, several small genera in Rhyparini (Termitodius, Termitodiellus, et al.), plus incertae sedis Termitaxis. One genus of similar morphology (Cartwrightia) and many more genera with more normal appearances are actually associated with ants. In several of the inquiline-type taxa, inquiline lifestyles have never been demonstrated; Stereomerini, a major part of Rhyparini (including Rhyparus), plus Notocaulus and Sybacodes (and Sybax). Instead, these are often found in forest litter, Notocaulus and Sybacodes also in dung. Of course, sifting forest litter and various trapping methods (light traps, Malaise traps, flight intercept traps) are far more common collecting methods than actually breaking into termite mounds. Thus, these taxa might be inquilines not yet encountered in their true habitat, or they may not live with social insects.

Typologies of social insect inquilines are from Wasmann $(1894,1903,1918)$, who also studied many of these aphodiines, like Kolbe (1909). Balthasar (1963) summarized the knowledge. Later, Wilson (1971) and Kistner (1979, 1982) provided general discussion of inquline types.

The basic division is between symphilic inquilines (those actually cared for by the hosts), and inquilines which are synoeketes (ignored by the hosts) or synechthrans (treated with hostility by the hosts). Morphologically, a symphilic lifestyle is often indicated by particular phenomena as possession of specialized tufts of glandular setae (trichomes) or enlarged abdomen (physogastry). Often, symphilic organisms display some kind of general morphological mimicking of their hosts. Synechtrans on the other hand are usually characterized with a "defensive" morphology, often very compact 
body (sometimes referred to as "limuloid" body shape, after horseshoe crabs (Limulus)), with reinforcing ridges and the capacity to withdraw protruding appendages into folds or grooves.

Among the aphodiines, Corythoderini, Termitoderini and Termitaxis clearly correspond to the "symphilic" type (and are indeed found with termites). The clearest examples corresponding to the "synechthran" type are presented by Termitotrogini and Stereomerini (the one found with termites, the other not recognized). The Rhyparini are probably best considered synechthran in general morphology, but less so than Termitotrogini and Stereomerini, and also have symphilic-type trichomes. The typical Rhyparini are not found with termites, and could be described as weakly synechthran in morphology. Within Rhyparini, only the more or less aberrant taxa are actually found among termites, often being intermediate between the weaker synechthran-type and symphilic-type morphologies.

\section{The rationale for classification of inquiline tribes}

It is unsatisfactory that this cluster of characters is regarded as an indication of a particular lifestyle in so many taxa where that lifestyle has not been observed. Some of them are commonly collected under circumstances giving no support whatsoever for that assumption. In aphodiine classification, various selections from this cluster are utilized to diagnose several aberrant tribes, while still being assumed to be intimately connected with a particular lifestyle and therefore largely homoplastic, and so not necessarily indicating a relationship between these different tribes while still keeping them together one by one. This is a problematic line of reasoning. A Darwinist framework still rests on interpreting similarities as the result of shared ancestry unless in conflict with other similarities. In this data set, the number of characters is small and the taxon sampling, particularly in various groups of possibly related Eupariini, is limited. For this reason, our results are uncertain and do not form the basis for any confidence in suggesting a revised tribal classification. Indeed the consistency is relatively low, but not extremely low, and there is a small number of most parsimonious trees, indicating that there is a fairly strong signal in the data. The Stereomerini, the core Rhyparini (excluding Sybacodes and Cartwrightia), and the Corythoderini, are all retained as monophyletic groups without conflict. All the representatives of aberrant taxa form a monophyletic group together.

Again, this is not a strong test, but the possibility that their similarities are to a significant extent due to shared ancestry rather than just shared lifestyle must be considered, especially since this particular lifestyle has in fact not been observed in so many of them. The aberrant or termitophilous tribes have been suggested to possibly be related to each other in a few works (Nikolajev 1993; Forshage 2002). Nikolajev suggests they could be related to each other and to Aulonocnemini. The phylogenetic status of Aulonocnemini is not well investigated, and it too might prove to be near or in Eupariini. 
The few representatives of Eupariini included, on the other hand, admittedly covering very little of the diversity of the group but nevertheless representing its three most principal genera, did not form a clade together, but instead a grade basal to a single clade of all the "termitophilic" tribes. Eupariini is historically delineated in contrast with Aphodiini, and most of its diagnostic characters are defined in that contrast. As the phylogeny of Aphodiinae remains uncertain, the polarity of most of these characters is not known. Regardless of whether the character states found in Eupariini are plesiomorphic or apomorphic visavis Aphodiini, they are either shared with or clearly plesiomorphic visavis Psammodiini and most minor tribes. In fact it seems impossible to circumscribe Eupariini as a monophyletic group. Eupariini may perhaps be a paraphyletic grade of basal groups of Aphodiini, or it may be a huge possibly monophyletic complex, but in both cases very possibly with Psammodiini and several smaller tribes intermixed.

A more robust phylogenetic analysis including a wealth of eupariine taxa, several of the minor tribes, and many more characters than used here, will highlight the difficuties of keeping Eupariini in its present form, and suggest a revised tribal classification. Whether this will result in the synonymy of several tribes into a solid Eupariini sensu lato, or identify monophyletic lineages that will allow for even further splitting into more tribes, will be up to the judgment of that revisor.

\section{Acknowledgements}

We express our gratitude to Bert Viklund for presenting the specimen of the new species to us. We thank Gary Wife at Department at the Biological Structure Analysis Group at the Evolutionary Biology Centre at Uppsala University for assistance with the scanning electron microscope. The Termitotrox type was found in material presented to MF by Roy Danielsson at the Museum of Zoology in Lund, Sweden, who also kindly provided the types of Adebrattia depressa, Pseudostereomera mirabilis and Danielssonia minuta. Torsten Nordander, The Natural History Museum in Gothenburg, was helpful in the return of the Termitotrox type. The constructive comments of two anonymous reviewers improved the manuscript considerably.

\section{References}

Balthasar V (1963-64) Monographie der Scarabaeidae und Aphodiidae der palaearktischen und orientalischen Region. 3 vols. Prag.

Bordat P, Howden HF (1995) Trois nouveaux genres, trois nouvelles espèces de Stereomerinae de Bornéo (Coleoptera, Aphodiidae). Bulletin de Société entomologique de France 100: 11-20.

Dellacasa G, Bordat P, Dellacasa M (2001) A revisional essay of world genus-group taxa of Aphodiinae. Memoire della Societá entomologica italiana 79: 1-482. 
Dellacasa M (1987-88) Contribution to a world-wide catalogue of Aegialiidae, Aphodiidae, Aulonocnemidae, Termitotrogidae (Coleoptera: Scarabaeoidea). Memorie della Società Entomologica italiana 66-67.

Dellacasa M (1991) Contribution to a world-wide catalogue of Aegialiidae, Aphodiidae, Aulonocnemidae, Termitotrogidae (Coleoptera: Scarabaeoidea). Addenda et Corrigenda (Second Note). Memorie della Società Entomologica italiana 70: 3-57.

Forshage M (2002) State of knowledge of dung beetle phylogeny- a review of phylogenetic hypotheses regarding Aphodiinae (Coleoptera; Scarabaeidae). Master's thesis, Biology, Uppsala, Sweden: Uppsala University: http://www.ebc.uu.se/systzoo/staff/forshage/Aphodiinae.pdf.

Galante E, Stebnicka ZT, Verdu, JR (2003) The Aphodiinae and Rhyparinae (Coleoptera: Scarabaeidae) in southern states of Mexico (Chiapas, Oaxaca, Puebla and Veracruz). Acta Zoologica Cracoviensia 46: 283-312.

Howden HF (1995) New Rhyparini from Fiji and the Philippines (Coleoptera: Scarabaeidae: Aphodiinae). Coleopterists bulletin 49: 23-27.

Howden HF (2003) Two new genera of New World Rhyparini. Sociobiology 42: 391-402.

Howden HF, Storey RI (1992) Phylogeny of the Rhyparini and the new tribe Stereomerini, with descriptions of new genera and species ((Coleoptera: Scarabaeidae: Aphodiinae). Canadian Journal of Zoology 70: 1810-1823.

Howden HF, Storey RI (2000) New Stereomerini and Rhyparini from Australia, Borneo and Fiji (Coleoptera: Scarabaeidae: Aphodiinae). Memoirs of the Queensland Museum 46: $175-182$.

Kistner DH (1979) Social and evolutionary significance of social insect symbionts. In: Herman HR (Ed) Social Insects, vol 1. Academic Press, New York, 339-413.

Kistner DH (1982) The social insects' bestiary. In: Herman HR (Ed) Social Insects, vol 3. Academic Press, New York, 1-244.

Kolbe H (1909) Die termitophilen Coleopteren aus der Unterfamilie der coprophagen Lamellicornier. Berliner Entomologischer Zeitschrift 54: 53-63.

Krikken J (1970) Termitaxis holmgreni gen. nov., sp. nov., a blind flightless termitophilous scarab from Peru (Coleoptera: Aphodiidae). Proceedings of the Koninklijke Nederlandse Academie van Wetenschappen. 73: 469-476

Krikken J (2008a) Two new species from Kenya in the physogastric termitophilous genus Termitoderus Mateu 1966 (Coleoptera Scarabaeidae Aphodiinae). Tropical Zoology 21: 153-162.

Krikken J (2008b) Blind, flightless termitophiles of the genus Termitotrox in East Africa; three new species with a generic review (Coleoptera: Scarabaeidae: Termitotroginae). Tjidschrift voor Entomologie 151: 65-75.

Krikken J, Huijbregts J (1987) Southeast Asian Termitodius: a taxonomic review, with description of four new species (Coleoptera: Aphodiidae). Zoologische Mededelingen 61: 97-111.

Maddison WP, Maddison DR (2005) MacClade-Analysis of phylogeny and character evolution. Version 4.08. Sinauer Associates, Sunderland, Massachusetts.

Makhan D (2006) Aschnarhyparus soesilae gen et sp nov from Suriname (Coleoptera: Scarabaeidae: Aphodiinae). Calodema 8: 7-11. 
Nikolayev GV (1993) The taxonomic placement in the subfamily Aphodiinae (Coleoptera, Scarabaeidae) of the new genus of lower cretaceous scarab beetles from Transbaykal. Paleontological Journal 27 (1A): 1-8.

Paulian R (1985) Notes sur les Coléoptères Scarabaeidae du Muséum de Geneve. II. Revue Suisse de Zoologie 92: 189-203

Pittino R (2006) Two new genera and species of Asian Rhyparinae (Coleoptera, Aphodiidae). Fragmenta Entomologica 38: 83-107.

Schmidt A (1910) Aphodiinae In: Junk W, Schenkling S (Eds) Coleopterorum Catalogus, pars 20. Junk, Berlin: 1-111.

Skelley PE (2007) Generic limits of the Rhyparini with respect to the genus Termitodius Wasmann, 1894 (Coleoptera: Scarabaeidae: Aphodiinae). Insecta Mundi 0009:1-9.

Skelley PE, Howden HF (2003) A new species of Lomanoxia Martínez from Costa Rica (Coleoptera: Scarabaeidae: Aphodiinae). Insecta Mundi 17: 185-190.

Stebnicka ZT (1999) Lomanoxia Martinez, 1951, and a new tribe Lomanoxiini with notes on comparative morphology (Coleoptera: Scarabaeoidea: Aphodiinae). Acta zoologica cracoviensia 42: 279-286.

Stebnicka ZT (2001) Aphodiinae (Insecta: Coleoptera: Scarabaeidae). Fauna of New Zealand 42, 64pp.

Stebnicka ZT (2009) The tribe Eupariini of the New World (Coleoptera: Scarabaeidae: Aphodiinae). Iconography II, Krakow, Institute of Systematics and Evolution of Animals, 135pp.

Storey RI, Howden HF (1996) Revision of Australoxenella Howden and Storey in Australia (Coleoptera: Scarabaeidae: Aphodiinae). Memoirs of the Queensland Museum 39: 365-380.

Swofford DL (2002) PAUP*. Phylogenetic Analysis Using Parsimony (*and Other Methods). Version 4. Sinauer Associated, Sunderland, Massachusetts.

Tangelder IRM, Krikken J (1982) Termitophilous scarabs of the tribe Corythoderini: a taxonomic review (Coleoptera: Aphodiidae). Zoologische Verhandelingen 194: 1-114.

Wasmann E (1894) Kritisches Verzeichnis der myrmekophilen und termitophilen Arthropoden Dames, Berlin: 231 pp.

Wasmann E (1903) Zur näheren Kenntnis des echten Gastverhältnisses (Symphilie) bei den Ameisen- und Termitengästen. Biologisches Centralblatt 23:63-72, 195-207, 232-248, 261-276, 298-310

Wasmann E (1918) Myrmecophile and termitophile Coleopteren aus Ostindien, hauptsächlich gesammelt von PJ Asmuth SJ. II. Scarabaeidae. Wiener entomologische Zeitung 37: 1-23.

Wilson EO (1971) The insect societies. Harvard University Press, 560 pp. 